\title{
Palestra w Wielkiej Brytanii w rozwoju historycznym
}

Ustrój palestry w Wielkiej Brytanii odróżnia się znacznie od systemów obserwowanych w krajach europejskich. Cechą najbardziej wyróżniającą jest podział funkcji pomiędzy dwie zasadnicze gałęzie zawodu, tj. solicitor i barrister, które są zaangażowane w tym samym charakterze w postępowaniu, ale pojawiają się rozłącznie na różnych jego etapach. Nadto warto zwrócić uwagę na wysoką specjalizację w ramach zawodu, która prowadzi do wyodrębnienia jego nowoczesnych gałęzi, takich jak pośrednik nieruchomości, rzecznik patentowy i znaków towarowych.

Jednym z powodów podjęcia niniejszych rozważań jest również wąski zakres opracowań dotyczących brytyjskiej palestry w polskiej literaturze historycznoprawnej, a szczególnie brak aktualnych analiz ${ }^{1}$, co w świetle dynamicznych zmian, jakim ten sektor podlega, jest szczególnie uciążliwe.

Stabilna struktura organizacyjna, która - jak to zostanie poniżej wykazane - tworzyła się przez wieleset lat, podlega obecnie głębokim przemianom. Głównym ich przejawem jest przyjęcie w październiku 2007 roku ustawy Legal Services Act, która wprowadza szereg zmian tak o charakterze instytucjonalnym, jak i proceduralnym. To zagadnienie, oprócz zarysu historii, również zostanie poruszone

1 W polskiej literaturze historycznoprawnej na uwagę zasługuje monografia M. Szerera, Sadownictwo angielskie, Warszawa 1959 oraz artykuły W. Babickiego, Organizacja adwokatury angielskiej, Palestra 1998, nr 8-9, s. 161-173 oraz B. Puchalskiej-Tych, Radcowie prawni i adwokaci $w$ Anglii, Jurysta 1994, nr 11, s. 31. 
w niniejszych rozważaniach, i to na podstawie analizy aktualnych źródeł normatywnych ${ }^{2}$.

W literaturze i źródłach pojawia się mnogość nazw służących określeniu zawodu prawnika. Należy tutaj wymienić słowa: advocate, attorney, pleader, countor, serjeant-at-law, narrator, counsel, conveyancer. Nie da się jednoznacznie rozróżnić funkcji wypełnianych przez przedstawicieli poszczególnych zawodów, ani prześledzić zależności genetycznych, jakie między nimi zachodziły. Bardziej uprawnione jest stwierdzenie, że współistniały one w sferze obsługi prawnej ludności Anglii i Walii, podejmując czynności zależnie od bieżących potrzeb i okoliczności, a nie zgodnie $z$ wytyczonymi granicami kompetencji. Takie limity należały przez długi czas do rzadkości i pojawiały się wyłącznie na najwyższym szczeblu. Tytułem przykładu można tutaj wskazać wyłączne prawo występowania przed Sądem Spraw Pospolitych (The Court of the Common Pleas) przyznane ok. 1318 roku najbardziej doświadczonej grupie prawników, których writ królewski z 1382 roku nazywa serjeant-at-law ${ }^{3}$.

Dyskusyjny jest również moment pojawienia się zastępstwa procesowego w angielskim wymiarze sprawiedliwości. Duża część autorów wskazuje na koniec wieku XIII, kiedy można mówić o w pełni zorganizowanej grupie zawodowej ${ }^{4}$. Z kolei Wilfrid Prest mówi o tym, że etap kształtowania się zawodów prawniczych rozpoczyna się po podboju normandzkim i przypada głównie na XI i XII wiek. Dowodem na to mają być sformułowania używane przez

2 Mowa tutaj o następujących ustawach Solicitors Act z 1974, Courts and Legal Services Act z 1990, Access to Justice Act z 1999, Legal Services Act z 2007 oraz dokumentach wewnętrznych korporacji prawniczych: Solicitors' Professional Rules oraz General Council of the Bar Code of Conduct.

3 D. Lemmings, Gentlemen and Barristers: The Inns of Court and the English Bar 1680-1730, Oxford University Press 1990, s. 2.

4 P. Tucker, First steps towards English legal profession, English Historical Review, Vol. CXXI, No. 481, s. 361-384. 
autorów dzieł prawniczych pochodzących z tamtego okresu, np. Glanvilla $^{5}$, Bracton ${ }^{6}$.

Jeszcze wcześniejsze pojawienie się profesji prawników dostrzega Hermann Cohen. Na dowód tego autor przytacza liczne źródła, pochodzące na długo sprzed najazdu normandzkiego. Pojawia się tu kodeks królów Kentu - Chlotara i Edryka7 ${ }^{7} 650$ rok), jak również traktat Edwarda Starszego $z$ królem duńskim Gutrunem ${ }^{8}$ (921 rok). W swoich rozważaniach Cohen idzie jeszcze dalej, upatrując początków adwokatury w hierarchii lennej ówczesnego społeczeństwa. W przypadku gdy wasal stawał przed oskarżeniem o popełnienie przestępstwa, powinnością seniora było stanąć w jego obronie. Wydaje się to dosyć śmiałą koncepcją, przeciw której można wysunąc szereg kontrargumentów. Po pierwsze zastępstwo, którego podejmuje się senior, jest jego obowiązkiem. $Z$ drugiej strony źródłem tego obowiązku jest swoisty kontrakt między wasalem a seniorem, co zbliża relację do stosunku zlecenia pomiędzy adwokatem i osobą przez niego reprezentowaną. Jest to jednak tylko pozorne

5 Ranulf Glanvilla, opisując postępowanie przed Izbą Wyższą Exchequeru, wskazuje, że strona procesowa może występować osobiście lub przez substytuta, por. T. Plucknett, A concise history of the common law, Longman 1956, s. 196 oraz D. Douglas, English Historical Documents, Longman 1956, s. 496.

6 F.M. Nichols, Britton - an English Translation and Notes, Waszyngton 1901, s. 611 i n., księga VI rozdział X Of Attorneys: „1. Attorneys cannot be made by every one; for an infant under age, a deaf and dumb person, an idiot, a man simply mad or otherwise without discretion, a person accused of felony, or any one who is forbidden by us to do so, or a leper expelled from society, cannot make an attorney".

7 Kodeks królów Kentu - Chlotara i Edryka, regulował głównie zagadnienia o charakterze prawnokarnym; w ustępie poświęconym sposobom odzyskania utraconego wskutek kradzieży mienia pojawia się łacińskie słowo advocatus. Por. H. Cohen, A history of the English Bar and Attornatus to 1450 , London 1929, s. 3.

8 Szczególnie istotny jest następujący ustęp przywołanego dokumentu: „If anyone seriously injures one in holy orders or a foreigner then the king or the bishop of the diocese shal be to him as a kinsman and protector (pro cognatione et advocatio) unless he has one already". Por. H. Cohen, A history of the English Bar and Attornatus to 1450, London 1929, s. 2. 
zbliżenie, gdyż występowanie seniora w toczącym się postępowaniu sądowym wynika nie $z$ podjęcia czynności obrończych, ale $z$ przejęcia odpowiedzialności za działanie lennika. Stąd teza stawiana przez Cohena wydaje się dyskusyjna i generalnie nie zyskała szerszego poparcia w literaturze.

Niezależnie od rozbieżności co do daty narodzin omawianej instytucji, autorzy wydają się zgodni co do faktu, że u schyłku XIII wieku profesjonalni zastępcy procesowi byli immanentnym elementem angielskiego procesu sądowego. Znajduje to potwierdzenie w dokumentach pochodzących $z$ drugiej połowy XIII wieku, takich jak: Speculum iuris (1275 rok), który precyzuje wymagania stawiane kandydatom do zawodu adwokata; Liber custumarum ${ }^{9}$ (1280 rok), gdzie znajdujemy czytelny podział na dwie gałęzie, określone jako attorneys (odpowiednik solicitor) oraz countors (odpowiednik barrister), a także zastrzeżenie, że countor nie może występować w charakterze attorney; De autoritatis et apprenticis (1292 rok), który określa sposób powoływania do wykonywania zawodu solicitora czy barrister, powierzając kompetencję do weryfikowania kandydatów sędziom Sądu Spraw Pospolitych. Nawiązując do uwag T. Plucknetta, należy stwierdzić, że jest to dokument o szczególnej wadze dla rozwoju palestry w Wielkiej Brytanii. Tworzy bowiem system edukacyjny, który ma zapewnić ciągłość wykonywania zawodu oraz stanowi przesłankę do stworzenia korporacji zawodowej ${ }^{10}$.

$Z$ uwagi na zaznaczoną już na wstępie mnogość form występowania zastępstwa procesowego wypada przeprowadzić próbę ich klasyfikacji. Niestety, również na tym tle dostrzega się szereg rozbieżności. Główna linia podziału biegnie pomiędzy prawnikami praktykującymi przed sądami prawa powszechnego (common law courts) a tymi, dla których właściwe było prawo cywilne (civil law), przez co rozumiemy prawo oparte na kodeksie justyniańskim oraz

9 Munimenta Gildhallae Londoniensis Liber Albus, Liber Custumarum et Liber Horn, ed. by H.T. Riley, Longman 1862, s. 461.

10 „Concerning attorneys and learners the lord King enjoined Mettingham and his fellows to provide and ordain at their discretion a certain number from every county of the better, worthier and more promising students and that those so chosen should follow the court and take part in its business and no others", cyt. za: T. Plucknett, op.cit., s. 199. 
prawo kanoniczne ${ }^{11}$. Podział ten znajduje odzwierciedlenie w charakterze edukacji otrzymywanej przez przedstawicieli tych dwu gałęzi zawodu. Większość $z$ nich to wychowankowie Inns of Court and Chancery, gdzie podstawą była praktyczna nauka oparta na obserwacji fikcyjnych procesów odgrywanych przez członków Inn (tzw. moots). Natomiast prawnicy cywiliści rekrutowali się niemal wyłącznie $z$ szeregów absolwentów uniwersytetów w Oxfordzie i Cambridge. Zrzeszali się w korporacji Doctors' Commons, która miała im zapewnić podobne zaplecze jak Inns of Court and Chancery $^{12}$.

Charakterystyczna dla Anglii przewaga sądownictwa powszechnego sugeruje raczej ograniczone możliwości rozwoju zastępstwa procesowego w ramach prawa cywilnego w powyższym znaczeniu. Nie należy jednak zapominać o szczególnych sądach, przed którymi postępowanie odbywało się w oderwaniu od reguł angielskiego prawa powszechnego ${ }^{13}$ - Sąd Kanclerski, Sąd Admiralicji, Sąd Próśb, Rada Północna, Rada Walijska. Ponadto gdy Henryk VIII zakazał wykładania prawa kanonicznego, w ręce tej grupy zawodowej przeszły kompetencje do występowania przed sądami kościelnymi, co oznaczało spory wolumen spraw małżeńskich, testamentowych i o przestępstwa obyczajowe. Nie ulega wątpliwości, że możliwości rozwoju zawodowego w ramach prawa cywilnego były ograniczone w stosunku do tych generowanych przez postępowania prowadzone zgodnie $z$ prawem powszechnym, co wydatnie przekładało się na liczebność obydwu grup.

Prawnicy praktykujący pod reżimem prawa powszechnego stanowili grupę daleką od jednorodności. Tutaj można wyodrębnić dwie podstawowe gałęzie, które dały początek współczesnej dychotomii zawodu, tj. serjeants-at-law - mający wyłączne prawo występowania przed Sądem Spraw Pospolitych, attorneys - pozostali przedstawiciele zawodu.

11 W.R. Priest, The Rise of the Barristers: A Social History of the English Bar, 1590-1640, Oxford University Press 1986, s. 45.

12 P. Tucker, First steps towards English legal profession, English Historical Review, Vol. CXXI, No. 481, s. 361-384.

13 K. Koranyi, Powszechna historia państwa i prawa, t. II, Warszawa 1955, s. 260. 
Zdecydowana większość autorów twierdzi, że były to grupy sobie współczesne. W przeciwnym kierunku podąża David Lemmings ${ }^{14}$, twierdząc, że o randze serjeants-a-law możemy mówić dopiero po roku 1382 , kiedy to ich powoływanie i związana $z$ tym ceremonia zostały usankcjonowane królewskim writem $^{15}$.

Przemiana, która wyznaczyła dalszy kierunek rozwoju zawodu, miała miejsce około 1318 roku, kiedy sędziowie Sądu Spraw Pospolitych zaczęli wskazywać imiennie oznaczonych pleaders o najdłuższym stażu i najbogatszym doświadczeniu i udzielać im prawa głosu na forum tego sądu ${ }^{16}$. Searjants-at-law odróżniali się od pozostałych przedstawicieli zawodu nie tylko ekskluzywnym uprawnieniem do występowania przed Sądem Spraw Pospolitych, ale również doniosłym faktem, że przynależność do tej grupy dawała duże szanse uzyskania nominacji sędziowskiej. To prowadziło do stopniowego powiększania dystansu w obrębie grupy prawników praktykujących zgodnie $\mathrm{z}$ prawem powszechnym ${ }^{17}$.

14 Podobnie T. Plucknett, op.cit., s. 196, przy czym ten autor posługuje się nazwą „narratores” w miejsce ,advocates”, ponadto jako źródło informacji na temat pojawienia się tej grupy wskazuje rejestry sądowe.

15 Godność sierżanta miała status urzędu publicznego, toteż powołanie do pełnienia tej funkcji wiązało się $z$ obowiązkiem przyjęcia nominacji. Jednakże ze względu na to, że taka nominacja była wyróżnieniem dla najbardziej zasłużonych pleaders, o co najmniej 16-letnim stażu pracy w zawodzie, był to raczej zaszczyt niż ciężar. Ilustracją tej tezy są słowa J. Fortescue, który twierdzi, że „brak innych przykładów ludzi biegłych w prawie, którzy zyskaliby więcej tytułu pełnionego urzędu niż sierżanci”. Aktu nominacji dokonywał Lord Kanclerz na wniosek Przewodniczącego Sądu Spraw Pospolitych podjęty po uzgodnieniu z pozostałymi sędziami tego sądu. Por. R.M. Jackson, The Machinery of Justice In England, Cambridge 1940, s. 189-190.

16 Praktyka ta została usankcjonowana wspomnianym już rytem królewskim z 1382 roku. Por. D. Lemmings, Gentlemen and Barristers, s. 4.

17 Zaznacza się to również w strukturze korporacji zawodowych serjeants-at-law zrzeszali się w odrębnych Inns of Court. Pierwsza powstała Inn przy Chancery Lane - 1416 r., następnie przy Fleet Street - 1443 r., por. S. Ireland, Picturesque views with a historical account of the inns of court, London 1800, s. 195-199. 
Swoją silną pozycję w palestrze serjeants-at-law utrzymali aż do XIX wieku. Początkiem końca tej gałęzi profesji była likwidacja monopolu występowania przed Sądem Spraw Pospolitych w 1845 roku, a następnie zniesienie ograniczeń praktykowania przed High Court i Court of Appeal. W konsekwencji u schyłku XIX wieku grupa ta całkowicie zanika ${ }^{18}$.

Elementem, który wydaje się łączyć ten historyczny kształt palestry z jej współczesnym ustrojem, jest zawód barristera. Termin ten pojawia się po raz pierwszy ok. 1518 roku w kronice prowadzonej przez Lincoln's Inn, gdzie służy określeniu studenta tej Inn. W ramach tej kategorii wyróżnia się później dwie grupy: inner-barristers oraz utter (outer)-barristers ${ }^{19}$, który to podział jest ściśle związany $z$ systemem edukacji w Inns of Court.

Ewolucja barristera studenta w barristera adwokata była procesem powolnym. Dopiero w sto lat od pojawienia się tej nazwy statut parlamentu z 1532 roku zalicza go do grona „uczonych w prawie”. Wreszcie sprawa Broughton v. Prince (1590 roku) skutecznie wskazała na praktykę $\mathrm{w}$ Inns of Court i w ślad za tym powołanie do palestry jako minimalny wymóg dla uzyskania prawa występowania przed sądem ${ }^{20}$. Należy uznać ten fakt za kluczowy dla ustalenia się rozdziału kompetencji między gałęziami zawodu i umocnienia pozycji Inns of Court, których uprawnienia w sferze edukacyjnej uzyskały sankcję prawa powszechnego.

18 Ostatnim sierżantem był Lord Nathaniel Lindley mianowany w $1899 \mathrm{r}$. Co ciekawsze, godność ta nie została jak dotąd formalnie zniesiona. Por. W.W. Boulton, Adwokatura w Anglii i Walii, Palestra 1958, nr 12, s. 27.

19 Podział ten nawiązuje do odbywanych w Inn moots, czyli symulacji rozprawy sądowej - inner-barristers byli to uczniowie o relatywnie krótkim stażu, którzy mogli tylko przypatrywać się prowadzonemu fikcyjnemu sporowi, podczas gdy outer-barristers brali czynny udział w takiej symulacji. Same określenia inner i outer mają swoje źródło w organizacji sali rozpraw w Sądzie Spraw Pospolitych, gdzie przestrzeń przeznaczona dla publiczności była oddzielona od sądu i stron za pomocą „kratki” (bar), D. Lemmings, Gentlemen and Barristes, s. 4.

20 Faktycznie aż do wybuchu rewolucji w 1648 r. słowo barrister nie było w powszechnym użyciu i posługiwano się raczej nazwami attorney czy serjeant, na stałe funkcjonowało jedynie w kronikach Inns of the court, W. Priest, op.cit., s. 5. 
Zaistnienie barristers na salach sądowych należy powiązać z dynamicznym wzrostem liczby powództw wnoszonych przed sądy westminsterskie, co wymusiło rozszerzenie katalogu osób uprawnionych do podejmowania czynności zastępstwa procesowego. Takie rozwiązanie nie spotkało się ze szczególnie przychylnym przyjęciem w środowisku sędziowskim. Dopiero wykazanie 7-letniej przynależności do Inns of Court i upływ co najmniej 3 lat od momentu powołania do palestry dawał barristers prawo występowania przed sądem ${ }^{21}$.

$\mathrm{W}$ potocznym rozumieniu barrister popiera twierdzenia mandanta w postępowaniu przed sądem. O ile było to zasadą przed sądami westminsterskimi, to w praktyce sądów prowincjonalnych spotykamy szereg odstępstw. Wydaje się, że taka zależność była podyktowana dwoistym charakterem sądów centralnych, które w określonych kategoriach spraw były sądami wyższymi właściwymi rzeczowo dla całej Anglii i Walii, a jednocześnie stanowiły regularny wymiar sprawiedliwości dla Londynu i okolic. Stąd wyłączność, jaką mieli najpierw serjeants, później również barristers, była łatwiejsza do wyegzekwowania również w sprawach, kiedy sądy westminsterskie procedowały w pierwszej instancji. Natomiast na prowincjonalnych sesjach sądowych zachowanie tego rozdziału było dużo trudniejsze.

Ciekawą tezę stawia Wilfrid Priest, argumentując, że dywersyfikacja zadań w ramach grup zawodowych opierała się nie tyle na ustalonych sztywno regułach, co raczej na oczekiwanych umiejętnościach, wiedzy i doświadczeniu osoby, której te czynności powierzano. Stąd barristers, których powołanie do palestry poprzedzało kilkuletnie kształcenie w Inns of Court, byli traktowani ze znacznie większym szacunkiem niż attorneys i solicitors, których czynności oceniano raczej jako powtarzalną, techniczną obsługę ${ }^{22}$.

Potwierdzeniem tezy Priesta jest traktat autorstwa sędziego sir Johna Dodderidga ${ }^{23}$, opublikowany w 1631 roku, w którym autor

21 W 1574 r. granicę tą obniżono do 5 lat, a w 1614 r. do 3 lat, W. Priest, op.cit., s. 13 .

22 W. Priest, op.cit., s. 12.

23 J. Dodderidge, The English Lawyer, Londyn 1632 - traktat, o którym mowa, ukazał się jako suplement do podręcznika przeznaczonego dla studentów Inns Of Court, por. W. Priest, op.cit., s. 14. 
wyodrębnia trzy działy pracy barrister, tj. porady prawne udzielane bezpośrednio klientom, przygotowywanie umów oraz popieranie twierdzeń mandanta przed sądem. $Z$ podziału wynika, że zawsze czynności barrister pokrywały się z wykonywanymi przez attorney, solicitor czy conveyancer. Do tej konkluzji przychyla się również David Lemmings ${ }^{24}$.

Ściślejszemu rozdzieleniu funkcji solicitors i barristers sprzyjała ewolucja prawa procesowego, szczególnie widoczna u schyłku XVI wieku, kiedy prymat zyskała zasada pisemności procesu, a spór ustny na sali sądowej stał się ostatnim stadium procesu i dotyczył tylko kwestii niedających się rozstrzygnąć w pisemnej części postępowania. Zmiany w procedurze znalazły odzwierciedlenie w modyfikacji charakteru sporu toczonego przed sądem - w miejsce relacji o okolicznościach pojawiła się szczegółowa dyskusja na temat prawa. W konsekwencji doszło do wypracowania szeregu skomplikowanych formuł procesowych. Przygotowanie tej części procesu włączono w zakres obowiązków barristers ${ }^{25}$.

Odmienny charakter dwóch gałęzi profesji trafnie ujmuje Tomasz Wood, definiując barristers jako doradców uczonych w prawie, uprawnionych do składania oświadczeń w ustnym postępowaniu przed sądem w celu obrony i ochrony interesów klienta. Natomiast rola solicitors sprowadza się zdaniem Wooda do postępowania w myśl rad barristers i dbałości o zabezpieczenie technicznej części postępowania $^{26}$.

Wieloletni rozwój angielskich instytucji zastępstwa procesowego doprowadził do ostatecznego ukształtowania dwóch jej odmian, występujących rozłącznie w postępowaniu przed organami wymiaru sprawiedliwości. W konsekwencji ogniwem znajdującym się najbli-

24 Lemmings określa barristers jako „vocation relatively elastic before victorian period” - D. Lemmings, Proffessors of the law, Oxford University Press 1990, s. 26.

25 Początkowo pojawiła się osobna grupa prawników specjalizujących się w przygotowaniu tej części postępowania (tzw. pleaders), ale było to zjawisko przejściowe, finalnie wchłonięte przez barristers. D. Lemmings, Professors of the law, s. 27.

26 T. Wood, An institute of the laws of England, London 1720, cyt. za: D. Lemmings, Professors of the law, s. 28. 
żej klienta poszukującego ochrony i porady jest solicitor, który udziela porad w mniej skomplikowanych problemach prawnych oraz uczestniczy w przygotowaniu szeregu dokumentów o prawnym znaczeniu, np. umowy, oświadczenia woli. Natomiast barrister będzie pojawiać się w tych sprawach, które wymagają rozstrzygnięcia przez sąd powszechny ${ }^{27}$, jak również bardziej skomplikowanych problemach prawnych. Tradycyjnie wyboru barrister dokonuje solicitor, a sam klient ma na to wpływ o tyle, że zazwyczaj solicitors współpracują z określonymi członkami Inns, specjalizującymi się w określonych dziedzinach prawa.

Zawody prawnicze ujęte zostały w ramy samorządności, którą realizowały poprzez swoje organy korporacyjne. Dla barristers była to Bar Council oraz the Inns of Court, podczas gdy solicitors zrzeszali się w Law Society. Na powstanie Law Society istotny wpływ miała postępująca izolacja drugiej gałęzi adwokatury, zrzeszonej $\mathrm{w}$ tradycyjnych Inns of Court ${ }^{28}$. O ile w XV wieku attorneys byli jeszcze dopuszczani do członkostwa w Inn, to u schyłku wieku XVI obserwuje się proces odwrotny. Tymczasem ta część profesji prosperowała coraz lepiej, co doprowadziło do utworzenia Society of Gentleman Practitioners In the Court of Law (1739). Organizacja ta zrzeszyła wszystkie odłamy zawodu solicitors, a wręcz spowodowała ich dyfuzję. $\mathrm{W}$ tym stanie rzeczy w $1831^{29}$ roku powstało

27 Jednocześnie ostatnie zmiany wprowadzone w systemie usług prawniczych wprowadzają wyłom od tej zasady, przyznając również solicitors ograniczone kompetencje występowania przed sądami niższych instancji. Dokładny podział kompetencji między solicitor a barrister oraz kompetencje innych praktyków występujących w obrocie usługami prawniczymi zob. tabela poniżej.

28 Por. ibidem.

29 Jest to pewne uproszczenie, gdyż proces powstania Inc. Law Society był bardziej rozłożony w czasie. W 1823 r. uformowano The London Law Institution, której celem było podniesienie standardów wykonywania zawodu. Dwa lata później odrzucono przymiotnik „londyńska”, aby podkreślić ogólnokrajowy charakter działania. Wtedy też powołano zarząd ILS, natomiast pierwszy statut uchwalono w 1831 r., stąd rozbieżności w literaturze co do czasu jego powołania. Por. www.lawsociety.org.uk. 
Incorporated Law Society ${ }^{30}$. Obecna nazwa - Law Society (LS), została wprowadzona w 1903 roku.

Ideą przewodnią tej korporacji jest dobrowolność - przynależność do Law Society nie jest w żadnym razie obowiązkowa ${ }^{31}$. Jednakże reguły, do ustanawiania których LS jest umocowane, są wiążące zarówno dla zrzeszonych, jak i niezrzeszonych solicitors. Od 1988 roku LS prowadzi ewidencję wszystkich praktykujących solicitors nazywana the roll ${ }^{32}$. Zasadnicze funkcje $\mathrm{LS}^{33}$ to kształcenie nowych adeptów rzemiosła prawniczego, kontrola dyscyplinarna, ustanawianie reguł wykonywania zawodu, weryfikacja praktykujących solicitors poprzez system certyfikatów, gromadzenie funduszu odszkodowawczego dla klientów ${ }^{34}$. Organem LS jest Council, na czele której stoi Master of the Rolls. Pierwotnie składała się z 25 członków, dzisiaj liczy 105 członków.

Samorządność barristers ma dużo dłuższe tradycje niż w przypadku solicitors. Podstawowym, a jednocześnie mającym najdłuższą tradycję organem korporacyjnym są Inns of Court, o których wzmianki znajdujemy w przekazach już z XIV wieku. Pierwotny charakter tych stowarzyszeń znajduje odzwierciedlenie w ich

30 Oficjalna nazwa The Society of Attorneys, Solicitor, Proctor and others not being Barristers Practising In the Court of Law and Equity of the UK - Towarzystwo Radców Prawnych oraz Innych Niebędących Adwokatami, którzy Praktykują przed Sądami Prawa i Słuszności Zjednoczonego Królestwa.

31 Pomimo to statystyki wskazują, że zdecydowana większość (ok. 85\%) solicitors należy do LS. Por. B. Puchalska-Tych, op.cit., s. 31.

32 Ciekawostką jest, że the roll była zbiorem miedzianych płytek $\mathrm{z}$ wygrawerowanymi na nich nazwiskami poszczególnych solicitors. Przywiązanie Anglików do tej tradycji sprawiło, że dopiero w 1975 r. uznano ten system za zbyt archaiczny i skomputeryzowano listę.

33 Jest to wyliczenie tradycyjnych kompetencji Law Society, jednak należy zwrócić uwagę na zmiany w przywołanym katalogu wprowadzone Legal Services Act z 2007 r. - por. niżej.

34 Od 1941 r. LS prowadzi tzw. Compensation Fund, tj. fundusz, z którego wypłacane są odszkodowania osobom, które poniosły szkodę wskutek niewłaściwego prowadzenia ich sprawy przez solicitors. Jest on gromadzony z obowiązkowych składek wnoszonych przez wszystkich praktykujących solicitors. Pełni funkcję podobną do obowiązkowego ubezpieczenia odpowiedzialności cywilnej radców obowiązującego w polskim systemie. 
nazwie - Inns of Court można przetłumaczyć jako 'Gospody Sądowe'. Ich głównym zadaniem było zapewnienie barristers warunków socjalnych umożliwiających pracę w czasie, gdy odbywały się roki sądowe. $Z$ czasem idea Inns rozszerzyła się na stworzenie optymalnych warunków dla wykonywania zawodu zarówno na poziomie socjalnym, jak i dydaktycznym ${ }^{35}$. Stąd ewoluowało swoiste kolegium, podobne do tych spotykanych na uniwersytetach w Cambridge czy Oxfordzie, w których skupiali się wykładowcy praktycy oraz ich studenci, a ich kontakty wykraczały poza sale wykładowe, gdyż razem mieszkali i spożywali posiłki ${ }^{36}$. Inn zrzesza trzy rodzaje członków: benchers (ławnicy) - organ zarządzający, outer barristers - adwokaci niemający tytułu Queens Counsel, inner barristers studiujący. Obecnie funkcjonują cztery Inns dla Anglii i Walii z siedzibą w Londynie, tj. Lincoln's Inn, Middle Temple, Inner Temple, Gray's Inn. Każdy barrister ma obowiązek przynależności do wybranej Inn.

Można przyjąć twierdzenie, że duży wpływ na powstanie Inns miał ordonans Edwarda I z 1292 roku $^{37}$. Przekazanie kontroli nad powoływaniem i praktyką barristers sędziom $z$ jednej strony, a $z$ drugiej strony wykluczenie duchowieństwa $z$ udziału w wymiarze sprawiedliwości spowodowało rozwój świeckiej adwokatury.

Najstarszy rodowód ma Lincoln's Inn, na co wskazują jego kroniki (tzw. Black Books) datowane od roku 1422. Jednakże z przekazu tych kronik wynika, że Lincoln's było w tym czasie już okrzepłym stowarzyszeniem, stąd wniosek, że powstało nawet do kilkudziesięciu lat wcześniej. Nazwa tego Inn pochodzi od jej patrona - Henryka

35 Edukacja w Inn nie była ograniczona tylko do studiowania prawa zwyczajowego - nauczano również takich przedmiotów jak muzyka, historia czy taniec. Stąd też zwyczaj, że zamożne rodziny wysyłały swych synów do Inn dla zdobycia przydatnego wykształcenia i ogłady, nawet jeśli nie mieli oni później wykonywać zawodu adwokackiego. Por. D. Lemmings, Gentlemen and Barristers, s. 8.

36 Pozostałością tego zwyczaju jest wymóg tzw. keeping dining terms w toku aplikacji adwokackiej, o czym później, por. R.M. Jackson, op.cit., s. 194-195.

37 P. Tucker, First steps towards an English Legal Profession, EHR, t. CXXI/491, s. 361-384. 
de Lacy, hrabiego Lincoln. $Z$ herbu patrona pochodzi również lew w godle Lincoln's.

Kolejne Inns: Middle Temple oraz Inner Temple, biorą swe nazwy od posiadłości będących niegdyś londyńską siedzibą templariuszy. Pierwsze wzmianki o Middle oraz Inner Temple datowane są na rok $1388^{38}$, jednakże najwcześniejsze kroniki tych stowarzyszeń pochodzą dopiero z 1501 i 1505 roku. Z szeregów tych Inns wywodziło się wielu słynnych prawników, ale również pisarzy i polityków, jak np. sir J. Littleton, sir E. Coke, Clement Attle, J.M. Keynes, J. Austin, E. Burke, W.M. Thackeray, Ch. Dickens.

Z kolei Gray's Inn jest uważane za najmłodsze ze stowarzyszeń. Pomimo wcześniejszych wzmianek, kroniki Gray's rozpoczynają się od roku 1569. Gray's Inn zdobył renomę nie tylko ze względu na swoją działalność edukacyjną, ale również szeroko pojętą działalność kulturalną.

Wiek XVI był dla Inns okresem szczególnej prosperity. Natomiast XVIII stulecie jest uważane za etap stagnacji, ponieważ przyjęcie do adwokatury $\mathrm{w}$ niewielkim stopniu zależało od zdobytego wykształcenia, raczej zaś od udziału w tradycyjnych obiadach organizowanych w Inn oraz rekomendacji sędziego lub ławnika ${ }^{39}$. Ten stan trwał do połowy XIX wieku ${ }^{40}$, gdy zarówno przedstawiciele adwokatury, jak i parlamentarzyści zaczęli dostrzegać potrzebę reformy systemu kształcenia ${ }^{41}$.

Jak już wyżej wskazano, Inns of Court miały swoje siedziby $\mathrm{w}$ Londynie, toteż barristers mający swoje kancelarie na prowincji zorganizowani byli w sześciu zgrupowaniach terytorialnych, nazy-

38 Rocznik z 1388 opisuje podniesienie kilku barristers do godności serjeant-at-law oraz wskazuje ich jako pochodzących medii tempi. Ponadto nawiązania do Middle Temple można odnaleźć we wstępie do Opowieści Kanterberyjskich Chaucera.

39 W. Babicki, op.cit., s. 162.

401832 Reform Bill.

41 Pierwszym krokiem na tej drodze było powołanie w 1852 r. Council of Legal Education. W latach 70. XIX w. (1872) wprowadzono system egzaminów poprzedzających przystąpienie do palestry. Po II wojnie światowej Rada przeniosła swoją siedzibę do Atkin Building i przybrała nazwę Inns of Court School of Law. 
wanych okręgami (circuits). Korzenie tej instytucji sięgają panowania Henryka II (1154-1189), który podzielił kraj na okręgi przydzielane jednemu lub wielu sędziom, podróżującym w granicach swojego okręgu z jednego miasta do drugiego. Sędziom towarzyszyli członkowie adwokatury, którzy łączyli się w grupy, wzorowane na londyńskich Inns. W ten sposób powstał zwyczaj wspólnego spożywania obiadu po sesji Trybunału i stąd też nazwa Ciruit Bar Messes. Anglia i Walia zostały podzielone na sześć okręgów: północny, północno-wschodni, środkowy i Oxfordu, południowo-wschodni, zachodni oraz walijski.

Okręgi te nie miały uprawnień takich jak Inns. Zajmowały się głównie działalnością socjalną na rzecz barristers ze swojego terenu, których reprezentowały przed władzami lokalnymi. W niewielkim zakresie sprawowały kontrolę dyscyplinarną. Barrister praktykujący na prowincji był jednocześnie członkiem jednego z Inns w Londynie oraz odpowiedniego circuit.

W drugiej połowie XIX wieku zaczęto dostrzegać potrzebę stworzenia jednolitej instytucji, która reprezentowałaby barristers jako całość - niezależnie od podziału na Inns czy circuits. W tym celu powołano w 1883 roku Bar Committe, który 12 lat później zastąpiono General Council of the Bar (1895). Organ ten został utworzony podczas walnych zgromadzeń adwokatury w latach 1894-1895. Bar Council otrzymała wyłączną kompetencję do reprezentowania barristers w Anglii i Walii. Obecnie składa się ze 115 członków, reprezentujących Inns of Court, circuits i inne organizacje zainteresowane działaniem palestry. Na czele rady stoi zarząd, w skład którego wchodzi prezes, wiceprezes oraz skarbnik, wybierani na roczną kadencję. Organem uchwałodawczym jest Walne Zgromadzenie Rady, które zbiera się około siedmiu razy w roku. Walne Zgromadzenie przyjmuje roczne sprawozdanie rady (annual statement), omawiające wyniki działalności rady za rok miniony. Rada działa poprzez 19 komisji, m.in.: wykonawcza, konduity zawodowej, reformy prawa, stosunków zewnętrznych, pomocy sądowej, szkolenia prawniczego.

Ciekawą odrębnością jest fakt, że aby uzyskać uprawnienia zawodowe, nie trzeba ukończyć uniwersyteckich studiów prawniczych. Law Society opracowało trzy różne drogi do zawodu solicitor, które 
są uzależnione od posiadanego wykształcenia. Jednocześnie każdy kandydat musi ukończyć dwa etapy szkolenia: akademicki i zawodowy.

Osoby, które ukończyły studia prawnicze na poziomie undergraduate, przystępują do kursu, którego ukończenie jest równoznaczne z uzyskaniem wyższego stopnia naukowego. Obejmuje on przedmioty uznane za podstawy angielskiego systemu, tj. prawo zobowiązań, prawo publiczne (administracyjne, konstytucyjne, praw człowieka), prawo karne, prawo majątkowe, equity oraz prawo handlowe, prawo UE. Kurs musi być ukończony w ciągu roku.

Natomiast osoby, które ukończyły kierunek inny niż prawo na uniwersytecie w Wielkiej Brytanii lub ukończyły studia i uzyskały tytuł magistra za granicą, mogą przystąpić do kursu The Common Professional Examination Course (inaczej The Graduate Diploma in Law Course). Jego ukończenie pozwala na przystąpienie do drugiego etapu szkolenia.

Wreszcie ostatnia ścieżka jest zaprojektowana dla osób bez wykształcenia prawniczego, które pracują w dziedzinach istotnie powiązanych $z$ prawem. W tym celu został powołany ILEX - Institute of Legal Executive. Kandydat, przystępując do Instytutu, zdaje egzaminy, uzyskując najpierw stopień członka (member), a następnie towarzysza (fellow). Ponadto obowiązuje wymóg zatrudnienia w zaakceptowanej przez ILEX instytucji.

Po ukończeniu akademickiego etapu szkolenia, co jest potwierdzone odpowiednim świadectwem wystawianym przez Law Society, można przejść do praktycznej nauki zawodu, która obejmuje dwie fazy. Pierwsza, Legal Practice Course (LPC), to praktyczny kurs organizowany przez instytucje zaaprobowane przez Law Society, który trwa rok. Następnie czas na praktykę w kancelarii prawniczej, dziale prawnym przedsiębiorstwa lub lokalnych władz, w prokuraturze lub sądzie miejskim. Podobnie jak w przypadku LPC, tylko praktyka w określonych, zaaprobowanych przez LS instytucjach daje podstawę do wystawienia świadectwa o ukończeniu tego etapu szkolenia. Niezbędnym elementem jest tutaj uzyskanie studenckiego członkostwa w LS. Kandydaci, którzy etap akademicki ukończyli w ramach ILEX, nie są objęci obowiązkiem odbycia praktyki zawodowej, aczkolwiek wszyscy, niezależnie od obranego sce- 
nariusza edukacji, muszą przystąpić do Professional Skills Course. Jest to 12-dniowy kurs organizowany przez instytucje wskazane przez LS.

Pomyślne zakończenie wymienionych etapów jest poświadczone przez LS odpowiednim świadectwem, które daje podstawę do wystąpienia o wpis na listę solicitors (tzw. roll). O taki wpis mogą również wystąpić prawnicy niepochodzący z Wielkiej Brytanii, ale praktykujący tam stale przez trzy lata. Warunkiem jest wcześniejsza rejestracja w LS.

Procedura zdobycia uprawnień barrister, podobnie jak i solicitor jest długotrwała i wieloetapowa. Obejmuje trzy stadia: szkolenie akademickie (academic stage), szkolenie zawodowe (vocational stage) oraz praktykę w kancelarii prawniczej (pupillage). Kandydaci, którzy mają dyplom studiów prawniczych, mogą przejść od razu do etapu szkolenia zawodowego (tzw. BVC - Bar Vocational Course), natomiast pozostali muszą ukończyć wcześniej już wspomniany kurs CPE/GDL. Podstawą do weryfikacji wiedzy zdobytej w czasie studiów czy egzaminu kończącego kurs jest siedem przedmiotów zakwalifikowanych jako podstawa angielskiego systemu prawnego.

Kolejnym krokiem jest złożenie wniosku o przyjęcie na aplikację do jednego $z$ Inn, co jest warunkiem przystąpienia do BVC. Kurs ten trwa rok. Integralną częścią tego etapu jest tzw. keeping dining terms, co nawiązuje do tradycji wspólnego spożywania posiłków w Inns. Również na tym polu wprowadzono istotne zmiany. Obecnie wypełnienie tego obowiązku może nastąpić na kilka różnych sposobów. Aby uzyskać nominację należy zebrać 12 tzw. jednostek, przy czym do każdej formy aktywności w ramach Inn przypisano odpowiednią liczbę jednostek. Przykładowo udział w weekendzie szkoleniowym w Inn został wyceniony na trzy jednostki, Dni Edukacji na dwie jednostki, natomiast kolacje edukacyjne ( $\mathrm{z}$ wykładami i dyskusją) na jedną jednostkę ${ }^{42}$.

Zwieńczeniem szkolenia jest roczna aplikacja u doświadczonego barrister. Przez pierwsze sześć miesięcy aplikant towarzyszy swemu

42 Por. R.M. Jackson, Machinery of Justice in England, Cambridge 1940, s. 194-196. 
patronowi podczas pracy, natomiast w drugim półroczu za jego zgodą może sam podejmować czynności zastępstwa procesowego. W trakcie aplikacji aplikant zostaje powołany do palestry, tzw. call to the Bar, przy czym drugie półrocze aplikacji może rozpocząć się dopiero po otrzymaniu nominacji.

Rekrutacja na aplikację odbywa się za pośrednictwem systemu OLPAS (on-line pupillage application system), gdzie kancelarie umieszczają informacje o dostępnych etatach. Nabór odbywa się w dwóch sesjach: letniej oraz jesiennej. Ideą tego systemu jest wyrównanie szans kandydatów przez zgromadzenie wszystkich ofert w jednym, powszechnie dostępnym miejscu oraz ustalenie wspólnego dla wszystkich kancelarii czasowego rozkładu naboru. Kandydaci mogą również odbyć tzw. małą aplikację (mini-pupillage), czyli krótką, zazwyczaj 2-tygodniową praktykę w kancelarii adwokackiej. Co do zasady, nie jest to obowiązkowe, aczkolwiek jest traktowane przez część patronów jako element procesu rekrutacji.

Wyraźną tendencją, która zaznaczyła się w europejskim prawodawstwie cywilnym schyłku XX wieku, jest dążenie do podwyższenia standardu ochrony klienta na rynku. Obecnie również w Wielkiej Brytanii zjawisko to stało się przyczynkiem do głębokiej reformy systemu usług prawniczych w tym kraju. Pierwszym krokiem na tej drodze był opublikowany w marcu 2001 raport Office of Free Trade pt. Competition in professions, stanowiący przegląd obowiązujących rozwiązań prawnych nieprzystających do promowanych standardów ochrony klienta różnorodnych usług. To zainicjowało podjęcie tego tematu przez stronę rządową, a w konsekwencji publiczną dyskusję w kwestii aktualnej kondycji tej gałęzi wymiaru sprawiedliwości ${ }^{43}$.

Kluczowe znaczenie dla dalszego kierunku prac nad reformą miał raport przygotowany na zlecenie Lorda Kanclerza przez sir Davida

43 Mowa tutaj o stanowisku rządowym wyrażonym w raporcie Competition and regulation in the legal service market (marzec 2003 r.), stanowiącym zbiór propozycji zmian aktualnego systemu. Znacząca jest konkluzja tego dokumentu, stwierdzająca, że obecny system jest przestarzały, nieelastyczny, ponad miarę skomplikowany i niewystarczająco przejrzysty. 
Clementiego ${ }^{44}$. Analiza przeprowadzona przez autora dokumentu wskazuje na główne przyczyny reformy, które w dużej mierze są spójne $z$ opinią wyrażoną przez rząd. Sir Clementi wymienia tutaj głównie przestarzałą, nieelastyczną strukturę systemu usług prawniczych, w którym organizacja korporacyjna nie odpowiada swoim współczesnym zadaniom. W dużej mierze jest to wynik niespójnego systemu nadzoru nad samorządem prawniczym, gdzie standardem są nakładające się uprawnienia kontrolne różnych organów zewnętrznych, co w konsekwencji prowadzi do paraliżu ich działania. $Z$ punktu widzenia ochrony klienta jako niezadowalający został oceniony również system skarg i zażaleń wymagający udrożnienia i zapewnienia minimalnych standardów bezstronności oceny. Wzmocnieniu statusu klienta nie służą ponadto liczne restrykcje, którym poddano formy organizacyjne, w jakich dostarczane są usługi prawnicze na rynek.

Wyżej wymienione zagadnienia determinowały dwa zasadnicze cele przeprowadzenia reformy, tj. cel ogólny, czyli stworzenie systemu, w którym wykonywanie zawodów prawniczych byłoby niezależne od zewnętrznych jak również wewnętrznych wpływów i służyło ochronie interesu publicznego, oraz cel szczególny, tj. rozszerzenie wachlarza prawnych form działalności w tym sektorze rynku, co będzie przekładało się na wzrost konkurencji, a w konsekwencji poprawę jakości dostarczanej usługi.

W kolejnej sekcji lord Clementi wskazuje na katalog celów i funkcji, takich jak wspieranie praworządności, zapewnienie możliwie szerokiego dostępu do wymiaru sprawiedliwości, ochrona i promocja interesów klienta na rynku, budowa silnego, efektywnego i godnego zaufania zawodu.

Ponadto postuluje powołanie nowych organów: Legal Service Board i Office of Legal Complaints, oraz rozszerzenie wachlarza form organizacyjnych świadczenia usług. Zarówno w przypadku

44 W dniu 24 lipca 2003 r. Sekretarz Stanu Lord Kanclerz Lord Falconer of Thoroton zwrócił się do członka Izby Lordów sir Davida Clementiego z wnioskiem o przygotowanie analizy struktury organizacyjnej usług prawniczych w Anglii i Walii. Termin dla złożenia raportu wyznaczono najpóźniej na 31 grudnia 2004 r. 
LSB, jak i OLC starły się ze sobą dwie koncepcje: organu administracji państwowej sprawującego nadzór nad określoną kategorią spraw (tzw. model „A”) oraz jednego organu zewnętrznego, właściwego dla wszystkich korporacji, ale niebędącego częścią aparatu administracji publicznej (tzw. model „B”). W obydwu przypadkach ostateczną przewagę uzyskał drugi model jako gwarantujący niezależność zawodu od nacisków zewnętrznych (głównie ze strony administracji państwowej) jak również wewnętrznych (przez oddanie kompetencji nadzorczych organowi niezwiązanemu bezpośrednio $\mathrm{z}$ organami reprezentacyjnymi korporacji). W odniesieniu do LSB za najkorzystniejszy uznano tzw. model „B+” ${ }^{45}$, w ramach którego korporacja została wyposażona w uprawnienie do samostanowienia, z zastrzeżeniem rozdzielenia funkcji regulacyjnej od reprezentacyjnej $^{46}$.

Kolejna zmianą o charakterze konstytutywnym jest powołanie Office of Legal Complaints ${ }^{47}$ - organu odpowiedzialnego za rozpatrywanie skarg i zażaleń na działanie prawników. Jest to rozwiąza-

45 Legal Sevices Act (2007) przyjmuje model „B”, jakkolwiek w procesie tworzenia tej regulacji preferowany był wariant „B+”. Natomiast rozdział funkcji regulacyjnej i reprezentacyjnej w samorządzie barristers jak również solicitors nastąpił przed wprowadzeniem nowej regulacji. Stąd organem odpowiedzialnym za regulacje dotyczące solicitors jest obecnie Solicitors Regulation Authority (wcześniej Law Society Regulatory Board), a w przypadku barristers - Bar Standards Board.

46 W zakres funkcji regulacyjnej wchodzi ustalanie standardów wykonywania zawodu i prowadzenia szkoleń, nadzór nad implementacją i przestrzeganiem tych zasad, postępowanie dyscyplinarne i skargowe. Na czynności reprezentacji natomiast składają się: ustalanie wysokości stawek wynagrodzenia za usługi, reprezentacja korporacji wobec rządu, podmiotów trzecich jak również na polu międzynarodowym, udzielanie informacji członkom korporacji oraz potencjalnym klientom. Por. D. Clementi, Review of the regulatory framework for legal services in england and wales final report, 2003, s. 14-15.

47 Istotna zmiana trybu załatwiania skarg nie pociągnęła za sobą reformy postępowania dyscyplinarnego - konkluzja sir Clementiego w tym zakresie okazała się zbieżna $z$ opinią organów korporacyjnych - jakkolwiek zunifikowanie tej części systemu poprawiłoby jego wydajność i spójność, dotychczasowego jego działanie należy ocenić pozytywnie. Znalazło to przełożenie na zachowanie dotychczasowych rozwiązań, tj. utrzymanie właści- 
nie bardzo istotne dla podniesienia standardu ochrony klientów, gdyż wprowadzenie wspólnego dla wszystkich zawodów organu rozpatrującego skargi znacznie upraszcza i przyspiesza proces załatwiania skarg.

Raport Clementiego poświęca sporo uwagi zagadnieniu dopuszczalnych form organizacyjnych swiadczenia usług prawniczych. W tym miejscu pojawia się kategoria Alternative Business Structures, w skład której wchodzą Legal Disciplinary Practices (LDP) oraz Multidisciplinary Practices (MDP) ${ }^{48}$. Za wprowadzeniem tych rozwiązań przemawia zwiększenie wydajności, idące $w$ parze $z$ obniżeniem kosztów dostarczanych usług, jak również wprowadzenie innowacji i zewnętrznego kapitału do analizowanego sektora. Wprowadzenie nowych rozwiązań wymagało jednak rewizji aktualnego stanu prawnego, obciążonego licznymi ograniczeniami, tj. zakazem tworzenia spółek między barristers lub barristers i innymi profesjonalistami, zakazem tworzenia spółek między solicitors i innymi profesjonalistami, zakazem świadczenia usług prawniczych na rzecz osób trzecich przez solicitor zatrudnionego przez firmę niebędącą jego własnością oraz zasadą, która stanowi, że barrister współpracuje $z$ klientem wyłącznie za pośrednictwem solicitor.

W odpowiedzi na raport lorda Clementiego w październiku 2005 roku rząd opublikował deklarację pod nazwą The Future of Legal Services: Putting Consumers First ${ }^{49}$, przedstawiającą porządek prac nad reformą. W ślad za tym w maju 2006 roku pod obrady izb parlamentu trafił projekt Legal Services Bill. Merytoryczną oceną tego projektu zajął się specjalnie w tym celu powołany Wspólny Komitet Izby Lordów i Izby Gmin. Wynikiem pracy Komitetu była nader krytyczna recenzja przedłożonego przez rząd projektu, wskazująca ponad 50 postanowień, których zapisy znacznie odbiegały od wniosków lorda Clementiego. Krytyka Komitetu skupiła się

wości Solicitors' Disciplinary Tribunal oraz Disciplinary Tribunal of the Four Inns of Court. Por. D. Clementi, Review of the regulatory framework for legal services in England and Wales final report, 2003, s. 51-81.

48 Co do składu i charakteru Alternative Business Structures - por. niżej.

49 Department for Constitutional Affairs Press Release 260/05, Consumers at heart of legal reforms, 17 October 2005. 
głównie na scentralizowaniu funkcji regulacyjnej, a w konsekwencji podważeniu niezależności wykonywania zawodów prawniczych i podniesieniu kosztów świadczonych usług (często zresztą przerzucanym ostatecznie na klienta). Ponadto przewidywane przez projekt zaangażowanie Sekretarza Stanu w proces regulacji i nadzoru nad korporacjami prawniczymi nie stanowiło należytej gwarancji niezależności Legal Service Board.

Kolejną ważną kwestią pozostawioną poza zakresem nowej regulacji było zagadnienie konfliktów kompetencyjnych pomiędzy organami właściwymi ds. skarg i zażaleń poszczególnych korporacji. Również w kwestii Alternative Business Structures projekt istotnie odbiegał od konkluzji raportu, poddając tę instytucję odrębnemu systemowi regulacji, co negatywnie odbiło się na realizacji postulatu przejrzystości nowego systemu ${ }^{50}$. W odpowiedzi na tę słuszną skądinąd krytykę rząd wystosował oświadczenie, w którym uznał zarzuty podniesione przez Komitet ${ }^{51}$. Przeprowadzona konsultacja połączonych izb parlamentu zaowocowała przedłożeniem w listopadzie 2006 roku Legal Services Bill. Dalsze prace nad ustawą trwały do 30 października 2007 roku, kiedy to została podpisana przez królową.

50 Trafną ilustracją jakości przedłożonego Billu jest opinia przewodniczącego Komitetu lorda Hunt of Wirral: „We have some very real concerns about the proposals put forward in this Bill. The draft Legal Services Bill departs from the recommendations of Sir David Clementi in a number of important respects and it is essential the Government should explain each of those departures fully. Most of our substantive recommendations would come under a single heading, namely that of going back to the future - the future envisaged by Clementi". Por. Joint Committee on the Draft Legal Services Bill Press Notice 2, Joint Committee raise concern over proposals in the Legal Services Bill, 25 May 2006.

51 Jako przyczynę ograniczonej realizacji postulatów reformy w przedłożonym projekcie rząd podał „zakłócenie delikatnej równowagi pomiędzy postulatem efektywnego procesu ustawodawczego a odpowiednią starannością” (,struck a sensible balance between early delivery and proper scrutiny"). Por. Government Response to the Report by the Joint Committee on the Draft Legal Services Bill, Session 2005-2006, Cm 6090, 25 September 2006. 
Legal Services Act składa się z 9 rozdziałów i 214 artykułów (sections). Integralną częścią ustawy są 24 załączniki, treść których stanowi uzupełnienie ogólnych zasad zawartych w ustawie.

Nazwą regulatory objectives ustawodawca objął ogólne zasady przesądzające o kształcie i interpretacji omawianego aktu. Zasady te można podzielić na dwie grupy: dyrektywy właściwe dla wszystkich gałęzi prawa publicznego oraz dyrektywy szczególne, znajdujące zastosowanie $z$ uwagi na przedmiot regulacji. Do pierwszej z grup należy zaliczyć ochronę interesu publicznego, wsparcie konstytucyjnej zasady rządów prawa, poprawę dostępu do wymiaru sprawiedliwości oraz budowanie publicznej świadomości praw i obowiązków obywatelskich. Zasadami powiązanymi z przedmiotem regulacji są $\mathrm{w}$ tym przypadku ochrona praw klienta, promocja konkurencji, utrzymanie zasad niezależności, efektywności i różnorodności zawodów prawniczych, przestrzeganie podstawowych zasad wykonywania zawodu.

Szczególnie istotne zmiany zaszły w płaszczyźnie ustroju głównych korporacji prawniczych. Ustawa z 2007 roku wprowadza nowe organy o kompetencjach nadzorczych, jak również znacznie uelastycznia ramy organizacyjne wykonywania zawodu.

LSB ma uprawnienia regulacyjne, $z$ których może korzystać tylko w przypadkach określonych w ustawie, podczas gdy ciężar bieżącej regulacji spraw korporacji spoczywa na organach samorządowych. Dla zachowania równowagi pomiędzy zewnętrznym nadzorem oraz codzienną działalnością korporacji stworzono 3-stopniową strukturę, która jednocześnie zapewnia realizację postulatów ustawowych, nie naruszając niezależności i integralności zawodu. Na elementy tejże struktury składają się: organ o funkcji wyłącznie reprezentacyjnej (np. Law Society, Bar Council), organ o funkcji wyłącznie regulacyjnej52 (odpowiednio Solicitors' Regulation Autho-

52 Są to organy o statusie tzw. approved regulators, których kompetencje ogniskują się na procesie udzielania licencji na świadczenie zastrzeżonych usług oraz ustanawianiu wewnętrznych zasad wykonywania zawodu. W dalszej kolejności można wymienić: ustanawianie wymogów minimalnych i regulaminu nauki dla aplikantów, postępowanie dyscyplinarne, postępowanie odszkodowawcze itd. Por. rozdz. IV Legal Services Bill 2007, sec. 27-70. 
rity, Bar Standards Board) oraz organ o charakterze zewnętrznym wobec korporacji, niebędący jednocześnie organem administracji państwowej (Legal Services Board).

Rozdzielenie funkcji reprezentacyjnej i regulacyjnej na poziomie korporacyjnym minimalizuje ryzyko wywierania wewnętrznego nacisku, który skutkowałby praktykami monopolistycznymi na rynku. $Z$ kolei stworzenie organu zewnętrznego mającego kompetencje w wąskim, ale ważnym zakresie dyscyplinuje działalność regulacyjną podejmowaną przez korporację. Jednocześnie brak powiązania $z$ rządem stanowi gwarancję utrzymania niezależności i integralności samorządu, które to cechy stanowią conditio sine qua non jego istnienia i działania.

Legal Services Board spełnia szereg funkcji, a wśród nich regulacyjną - dużą część swoich kompetencji LSB deleguje na rzecz organów korporacyjnych ${ }^{53}$, czyniąc tym samym zadość głównym założeniom reformy - faktyczny ciężar regulacji spoczywa na samorządzie zawodowym, $z$ zachowaniem uprawnień nadzorczych po stronie LSB; postulatywną - są to idee istnienia i działania LSB, brak jednak wskazania, co do środków, które miałyby służyć ich realizacji. Tutaj należy wymienić wzmacnianie zaufania obywateli do obowiązującego prawa oraz praworządności, ochronę interesów klientów, dążenie do efektywnej regulacji i realizację polityki wolnej konkurencji w sektorze usług prawniczych. Dodatkowo w odniesieniu do standardów uprawiania zawodów barrister czy solicitor do LSB należy troska o zachowanie niezależności zawodu, integralność wykonywania zawodu - obecna na płaszczyźnie stosunków z klientami, sądami i urzędami jak również w łonie organizacji samorządowej, zabezpieczenie interesu klienta, poszanowanie przywilejów zawodowych, np. tajemnicy zawodowej, zapewnienie transparentnych zasad dostępu do usług prawniczych jak również do wykony-

53 Analizując tę kwestię, należy zwrócić uwagę na kategorie: „approved regulator”, „authorised persons” oraz „reserved legal activities” - przeniesienie kompetencji z LSB na organy korporacyjne (,approved regulator”) następuje przede wszystkim przez przyznanie tym organom prawa udzielania licencji (,authorisation”) na wykonywanie usług prawniczych zastrzeżonych dla profesjonalnych zastępców procesowych. Por. Legal Services Act 2007, sec. 12, 18. 
wania zawodu - ze szczególnym uwzględnieniem polityki niedyskryminacji.

Dominującym motywem reformy jest w tym przypadku ochrona praw klienta, czego przejawem jest utworzenie agendy subsydiarnej wobec LSB - Consumers' Panel. W praktyce uprawnienia CP są urzeczywistniane $\mathrm{w}$ formie wnioskó ${ }^{54}$ skierowanych do LSB, z którymi LSB ma obowiązek zapoznać się, a w przypadku odrzucenia również uzasadnić.

Legal Services Act dokonuje również swoistej weryfikacji zakresu uprawnień poszczególnych zawodów przez ujednolicenie kategorii zastrzeżonych usług prawniczych (reserved legal activities). Nie jest to pojęcie nowe, stworzone dla potrzeb reformy, jednak omawiana ustawa wprowadziła w tym zakresie jednolite kryterium wyodrębnienia ${ }^{55}$ i zasadę numerus clausus ${ }^{56}$ zastrzeżonych usług prawniczych. Kategorię tę tworzą następujące czynności obsługi prawnej: prawo występowania przed sądem, prawo inicjowania i prowadzenia postępowań spornych, czynności w zakresie obrotu majątkiem ruchomym lub nieruchomym, czynności w postępowaniu probacyjnym, przyjmowanie uroczystych oświadczeń woli lub wiedzy, czynności notarialne.

Uprawnienie do świadczenia usług zastrzeżonych płynie $z$ licencji udzielonej przez odpowiednio umocowany organ korporacyjny. W zależności od korporacji, różny jest zakres licencji, co ilustruje poniższa tabela ${ }^{57}$ :

54 Dodatkowo LSB może zlecić CP przygotowanie opinii w określonej kwestii - wówczas rodzi się obowiązek zapoznania się z nią, a w razie nieuwzględnienia również obowiązek uzasadnienia. Por. Legal Services Act 2007, sec. 8-11.

55 Przed wejściem w życie Legal Services Act była to kategoria uregulowana cząstkowo w różnych aktach prawnych, po części z uwagi na podmiot uprawniony do wykonywania określonych usług, a po części na podstawie charakteru tej usługi.

56 Jest to katalog zamknięty, a jego rozszerzenie może nastąpić jedynie wskutek nakazu Lorda Kanclerza wydanego na wniosek LSB. W takiej sytuacji uprawnienie do przyznawania licencji jest przypisane LSB, nie właściwej rzeczowo i osobowo korporacji. Por. Legal Services Act, sec. 24.

57 Oprac. własne na podstawie Legal Services Act 2007, schedule 2, s. $128-129$. 


\begin{tabular}{|c|c|c|}
\hline P. & $\begin{array}{l}\text { ORGAN } \\
\text { KORPORACYJNY }\end{array}$ & WŁAŚCIWE ZASTRZEŻONE USŁUGI PRAWNICZE \\
\hline 1 & The Law Society & $\begin{array}{l}\text { 1. Prawo występowania przed sądem. } \\
\text { 2. Prawo inicjowania i prowadzenia } \\
\text { postępowań spornych. } \\
\text { 3. Czynności w zakresie obrotu majątkiem } \\
\text { ruchomym lub nieruchomym. } \\
\text { 4. Czynności w postępowaniu probacyjnym. } \\
\text { 5. Przyjmowanie uroczystych oświadczeń woli } \\
\text { lub wiedzy. }\end{array}$ \\
\hline 2 & $\begin{array}{l}\text { The General } \\
\text { Council of the } \\
\text { Bar }\end{array}$ & $\begin{array}{l}\text { 1. Prawo występowania przed sądem. } \\
\text { 2. Prawo inicjowania i prowadzenia } \\
\text { postępowań spornych. } \\
\text { 3. Czynności w zakresie obrotu majątkiem } \\
\text { ruchomym lub nieruchomym. } \\
\text { 4. Czynności w postępowaniu probacyjnym. } \\
\text { 5. Przyjmowanie uroczystych oświadczeń woli } \\
\text { lub wiedzy. }\end{array}$ \\
\hline 3 & $\begin{array}{l}\text { The Master of the } \\
\text { Faculties }\end{array}$ & $\begin{array}{l}\text { 1. Czynności w zakresie obrotu majątkiem } \\
\text { ruchomym lub nieruchomym. } \\
\text { 2. Czynności w postępowaniu probacyjnym. } \\
\text { 3. Przyjmowanie uroczystych oświadczeń woli } \\
\text { lub wiedzy. } \\
\text { 4. Czynności notarialne. }\end{array}$ \\
\hline 4 & $\begin{array}{l}\text { The Institute of } \\
\text { Legal Executives }\end{array}$ & $\begin{array}{l}\text { 1. Przyjmowanie uroczystych oświadczeń woli } \\
\text { lub wiedzy. } \\
\text { 2. Prawo występowania przed sądem. }\end{array}$ \\
\hline 5 & $\begin{array}{l}\text { The Council for } \\
\text { Licensed } \\
\text { Conveyancers }\end{array}$ & $\begin{array}{l}\text { 1. Czynności w zakresie obrotu majątkiem } \\
\text { ruchomym lub nieruchomym. } \\
\text { 2. Przyjmowanie uroczystych oświadczeń woli } \\
\text { lub wiedzy. }\end{array}$ \\
\hline 6 & $\begin{array}{l}\text { The Chartered } \\
\text { Institute of } \\
\text { Patent Attorneys }\end{array}$ & $\begin{array}{l}\text { 1. Prawo występowania przed sądem. } \\
\text { 2. Prawo inicjowania i prowadzenia } \\
\text { postępowań spornych. } \\
\text { 3. Czynności w zakresie obrotu majątkiem } \\
\text { ruchomym lub nieruchomym. } \\
\text { 4. Przyjmowanie uroczystych oświadczeń woli } \\
\text { lub wiedzy. }\end{array}$ \\
\hline 7 & $\begin{array}{l}\text { The Institute of } \\
\text { Trade Mark } \\
\text { Attorneys }\end{array}$ & $\begin{array}{l}\text { 1. Prawo występowania przed sądem. } \\
\text { 2. Prawo inicjowania i prowadzenia } \\
\text { postępowań spornych. } \\
\text { 3. Czynności w zakresie obrotu majątkiem } \\
\text { ruchomym lub nieruchomym. } \\
\text { 4. Przyjmowanie uroczystych oświadczeń woli } \\
\text { lub wiedzy. }\end{array}$ \\
\hline
\end{tabular}


Wskazując na funkcje LSB, powiedziano o uprawnieniach kontrolnych wykonywanych przez ten organ w stosunku do organów korporacyjnych. Główne kwestie podlegające kontroli to realizacja celów reformy oraz zgodność $z$ zasadami wewnętrznego zarządu ${ }^{58}$. W przypadku stwierdzenia nieprawidłowości w działaniu korporacji LSB inicjuje postępowanie naprawcze. W pierwszej kolejności wydaje wiążące zalecenia w celu zlikwidowania istniejących uchybień. Niezastosowanie się organu korporacyjnego do tych zaleceń otwiera drogę do wniesienia skargi do High Court.

Ponadto LSB przysługuje uprawnienie do nałożenia na korporację kary pieniężnej. Strona zobowiązana do zapłaty ma prawo skargi do sądu. W postępowaniu przed sądem mogą zostać podniesione takie zarzuty, jak: przekroczenie uprawnień przez LSB, niezachowanie procedury nałożenia kary lub wysokość kary nieadekwatna do zawinienia. Sąd może rozstrzygnąć na korzyść korporacji, wówczas kara może być anulowana, obniżona lub prolongowana.

Drugim $z$ filarów reformy jest zmiana systemu rozpatrywania skarg konsumenckich. Dotychczasowa procedura dochodzenia roszczeń z tytułu odpowiedzialności zawodowej barrister lub solicitor oparta była na negocjacjach stron, a gdy tą drogą nie osiągnięto porozumienia, pozostawało postępowanie przed odpowiednim organem korporacji. Klient niezadowolony z rozstrzygnięcia organu samorządu zawodowego mógł w ostateczności zwrócić się do Legal Services Ombudsmana.

Główne zarzuty, jakie wysunięto przeciwko dotychczasowemu systemowi, dotyczyły niskiej wydajności systemu, wysokich nakładów ponoszonych przez korporacje na utrzymanie procedur skargowych $^{59}$, konfliktów kompetencyjnych pomiędzy organami właści-

58 Ta kwestia stanowi realizacje celów reformy jak również jednego z głównych postulatów sir Clementiego, tj. rozdziału funkcji regulacyjnej i reprezentacyjnej - postępowanie kontrolne ma wykazać, czy funkcje dzierżone przez korporacje zachowują odpowiednią równowagę, a zatem czy decyzje podejmowane w ramach funkcji regulacyjnej nie są zdeterminowane realizacją funkcji reprezentacyjnej i na odwrót.

59 W 2007 r. koszt postępowań skargowych wyniósł około 33 mln funtów, z czego ponad 86\% stanowiły koszty skarg przeciwko solicitors. Por. Legal Services Act 2007, Research Paper, No. 2, s. 48. W związku z tym 
wymi do rozpatrywania skarg w różnych korporacjach ${ }^{60}$, brak zgodności $z$ jedną $z$ podstawowych zasad państwa prawa - nemo iudex in causa sua ${ }^{61}$.

Włączenie zagadnienia skarg i zażaleń w zakres prac nad reformą systemu usług prawniczych wzbudziło wyraźny sprzeciw Bar Council, motywowany wysoką rozbieżnością między liczbą skarg na postępowanie barristers a liczbą skarg skierowanych przeciwko solicitors. W odpowiedzi na tę opinię Komitet Parlamentarny pracujący nad projektem ustawy podtrzymał dotychczasowe stanowisko w kwestii przyjęcia regulacji obejmującej wszystkie zawody prawnicze, argumentując, że bezpośredni kontakt barrister z klientem ma miejsce w wyjątkowych przypadkach, natomiast solicitor, będący pierwszym ogniwem obsługi prawnej, jest narażony na wielokrotnie wyższe ryzyko. Wprowadzenie systemu Alternative Business Structures, w którym barristers będą mogli pracować $\mathrm{w}$ ramach tej samej struktury organizacyjnej z solicitors, a więc również $\mathrm{w}$ bezpośrednim kontakcie $\mathrm{z}$ klientami, stanowi prognozę realnego wzrostu liczby skarg.

W rezultacie nowa regulacja przewiduje utworzenie Office of Legal Complaints - zewnętrznej agendy odpowiedzialnej za rozpoznawa-

w lutym 2004 r. powołano Legal Services Complaints Commissioner, urzędnika odpowiedzialnego za poprawę jakości i średniego czasu załatwiana skarg przeciw solicitors (po wejściu w życiu Legal Services Act 2007 urząd ten jak również Legal Services Ombudsman zostały zniesione).

60 Źródłem licznych sporów kompetencyjnych między właściwymi organami korporacji solicitors i barristers była sama organizacja obsługi prawnej. Powiązanie obydwu zawodów częstokroć utrudniało ustalenie odpowiedzialności, a w konsekwencji organu właściwego do rozstrzygnięcia skargi.

61 W przypadku samorządu zawodowego barristers organem właściwym do rozpoznawania skarg jest Bar Standards Board, czyli organ odpowiedzialny za funkcję regulacyjną. Natomiast w przypadku Law Society skargi są rozpoznawane przez Consumers' Complaint Service - organ odpowiedzialny wyłącznie za procedury skargowe. Jednakże zgodność z przytoczoną zasadą nemo iudex jest w drugim przypadku złudna, gdyż rozdział kompetencyjny nie poszedł w parze $z$ niezależnością finansową i organizacyjną. Por. D. Clementi, Review of the regulatory framework for legal services in England and Wales, London 2004, s. 51. 
nie skarg skierowanych przeciwko przedstawicielom wszystkich zawodów prawniczych. Jest to organ wolny od wpływów korporacji zawodowych, a jednocześnie podlegający LSB, która ustala politykę i główne cele OLC. Przewodniczący OLC jak również większość członków będą osobami spoza środowiska korporacyjnego.

Office of Legal Complaints LC dysponuje w postępowaniu kilkoma rodzajami sankcji: przeprosiny, obniżenie wynagrodzenia lub jego zwrot w całości albo części, wypłata odszkodowania, pokrycie kosztów lub inna przewidziana przepisami czynność. Ogólne obciążenia finansowe $z$ tytułu skargi wniesionej przed OLC nie mogą przekroczyć 30 tys. funtów. W przypadku kiedy pozwany nie uczyni zadość rzeczonym obowiązkom, skarżący może zwrócić się do sądu powszechnego.

Również zagadnienie procedur dyscyplinarnych zostało poddane analizie pod kątem zgodności z ogólnymi celami reformy. Jakkolwiek wyniki tych badań nie mogą zostać uznane za wzorcowe, to zdaniem najbardziej zainteresowanych środowisk obecny stan regulacji pozwala na satysfakcjonujące rozstrzyganie spraw dyscyplinarnych i brak jest przesłanek, by twierdzić, że powierzenie tych zadań organom korporacyjnym wypacza wynik postępowania. Co więcej, znalazło to także odzwierciedlenie w zapisach nowej ustawy, gdzie wprowadza się zasadę, że wykryte w postępowaniu skargowym fakty, mogące stanowić przesłankę wszczęcia postępowania dyscyplinarnego, powinny zostać przekazane do właściwych organów korporacyjnych.

Akty prawa wewnętrznego interesujących nas korporacji zawodowych, tj. Solicitors' Practice Rules i Law Society Bye-Laws dla solicitors oraz Code of Conduct dla barristers, określają model organizacyjny, w ramach którego przedstawiciele tych zawodów współistnieją na rynku. Tradycyjnie był on obarczony szeregiem restrykcji, szczególnie w zakresie możliwości zakładania spółek „partnerskich” ${ }^{2}$.

62 Jako przykład należy wymienić tutaj zakaz tworzenia spółek pomiędzy barristers jak również pomiędzy barristers i przedstawicielami innych zawodów prawniczych lub nieprawniczych, zakaz samodzielnego nawiązywania przez barrister kontaktu $z$ klientem. Pierwszy istotny wyłom w tej kwestii poczyniono w 1989 r., przyznając prawo zwracania się po poradę bezpośrednio do adwokata członkom związków zawodowych, policji i nie- 
W celu wyeliminowania istniejących dotychczas ograniczeń Legal Services Act wprowadza tzw. Alternative Business Structures (ABS). Idea tego rozwiązania polega na stworzeniu szerokiego wachlarza możliwości współdziałania na rynku prawników z różnych gałęzi zawodu. Kategoria ta dzieli się na dwa zakresy: Legal Disciplinary Practices i Multi-Disciplinary Practices. W pierwszym przypadku będziemy mówić o spółce prawników o różnych specjalizacjach, którzy pracują razem na równych zasadach. Natomiast druga sytuacja to firma o szerokim zakresie działalności, która łączy umiejętności i wiedzę specjalistów z różnych dziedzin, w tym prawników.

Projekt omawianych zmian spotkał się $z$ przychylnym przyjęciem Law Society, czego nie można natomiast powiedzieć o Bar Council. Argumentami, które przemawiały za przyjęciem tego rozwiązania, były większa wydajność pracy, obniżenie kosztów, większe możliwości rozwoju i wprowadzania innowacji, wreszcie możliwość przyciągnięcia nowego kapitału (zwłaszcza na bazie MDP). Odpowiedź ze strony Bar Council została sformułowana przez sir Patricka Kentridge'a $Q C$, który stwierdzał, że umożliwienie dyfuzji środowisk prawniczych doprowadzi do ostatecznego upadku specjalizacji zawodu barrister, co w konsekwencji zaowocuje gorszym przygotowaniem merytorycznym i obniżeniem się poziomu jakości świadczonych usług; ABS nie realizują w pełni podniesienia standardu ochrony praw klienta, gdyż połączenie barristers w duże kancelarie bi- lub multiprofesjonalne spowoduje podniesienie stawek; jednym $z$ niewielu racjonalnych argumentów w tym dyskursie jest kwestia częściowego paraliżu, tzw. cab-rank rule, stanowiącej ważną gwarancję procesową, zwłaszcza w procesie karnym ${ }^{63}$.

których organizacji korporacyjnych. Kolejne zasadnicze zmiany wprowadziła poprawka do General Council of the Bar Code of Conduct (\$ 603h). Stanowi ona, że barrister może przyjąć sprawę bezpośrednio od klienta, bez instrukcji solicitors. Istotne jest tutaj zastrzeżenie, że jest to uprawnienie adwokata, nie jego obowiązek. Jednocześnie dotyczy to tylko adwokatów o co najmniej 3-letnim stażu, którzy spełniają wymagania określone przez Bar Council oraz dopełnili stosownego obowiązku notyfikacyjnego.

63 Oznacza to obowiązek przyjęcia każdej sprawy, z jaką zwróci się do niego solicitor. Jednakże istnieją przesłanki, które umożliwiają uchylenie się od tej powinności. Przede wszystkim są to okoliczności, które mogłyby 
Nie brakowało jednak argumentów przemawiających za wprowadzeniem opisywanych zmian. Z punktu widzenia solicitors, działających często w charakterze pośredników, ABS umożliwia lepsze zestawienie potrzeb klienta ze specjalizacją barristers, a ponadto daje lepsze spojrzenie na jakość usług przez nich świadczonych. Przeważającym jednak argumentem wydaje się motyw przewodni tej reformy, tj. dążenie do zwiększenia standardu ochrony klienta

postawić danego adwokata w kłopotliwej zawodowo sytuacji, np. gdy brakuje mu odpowiedniego doświadczenia lub $\mathrm{z}$ uwagi na inne zobowiązania nie może poprowadzić sprawy z należytą starannością, zachodzi ryzyko ujawnienia informacji objętych tajemnicą adwokacką. Na tle tej zasady bardzo często przywołuje się casus słynnego barrister Tomasza Erskine’a, który podjął się obrony Toma Paine'a, autora niepochlebnych komentarzy o Wilhelmie III i Jerzym I, mimo wielu nacisków, aby odrzucił tę sprawę. Wówczas padły pamiętne słowa: „Raz na zawsze chciałbym potwierdzić godność, niezależność i nienaruszalność adwokatury angielskiej, bez których bezstronna sprawiedliwość, będąca najważniejszą cząstką konstytucji angielskiej, nie może istnieć. Od tej chwili, kiedy adwokat ma prawo powiedzieć, że wystąpi lub nie - od tej chwili pomiędzy Koroną a poddanym postawionym przed sądem wchodzą w grę wolności Anglii. Jeżeli adwokat odmawia zapewnienia obrony w związku $\mathrm{z}$ tym, co może myśleć o oskarżeniu i o środkach obrony, odgrywa rolę sędziego; nawet przed zapadnięciem wyroku, odpowiednio do swej rangi i do swojej reputacji, może on stworzyć błędną opinię mogącą przeważyć szalę na niekorzyść oskarżonego, na rzecz którego działa jednak presumpcja życzliwości - zasada prawa angielskiego, która poleca nawet sędziemu stawać się adwokatem oskarżonego". Cyt. za: W. Babicki, op.cit., s. 170.

Jest to zasada, która budzi kontrowersje w szeregach palestry. Przez jednych uważana za chlubę zawodu adwokata (por. dyskusja w Izbie Gmin z 28 stycznia 1998 r. Lord Kanclerz: „The "cab rank" rule is one of the glories of the Bar. It underscores that every member of the Bar is obliged, without fear or favour, to represent clients who offer themselves, regardless of how unpopular they may be in the community or elsewhere"), przez innych jest postrzegana jako zamach na niezależność wykonywania zawodu (tak G. Webber w artykule pt. A barrister's right to choose, opublikowanym w The Times (18.06.2000): „The 'cab-rank' rule is a restriction on freedom. [...] At its most extreme, this rule requires a black or Jewish barrister to act for a Nazi. In most cases a barrister can be expected to act with professional detachment but in such circumstances he or she is being asked to be less than human"). 
na rynku usług prawniczych. Nie należy mieć wątpliwości, że uelastycznienie form organizacyjnych, w jakich dopuszcza się świadczenie przedmiotowych usług, zwiększą konkurencję na rynku, co przekłada się na poprawienie pozycji ich klienta.

Jak zostało to wykazane, pierwotnie podział profesji na dwie gałęzie wg charakteru czynności zawodowych nie był skonkretyzowany. Samo powołanie do palestry (call to the bar) nie eliminowało czynności doradczych właściwych dla solicitor. Ścisły rozdział funkcji był procesem powolnym i długotrwałym - w miarę uznawania danych czynności za „techniczne” jak również w procesie tworzenia proporcji liczebnej obydwu zawodów następowało ich przesunięcie do zakresu zadań solicitor. Wypracowany w długim rozwoju podział czynności ulega dziś istotnemu zatarciu - praca barrister coraz rzadziej ogranicza się jedynie do popierania twierdzeń mandanta w postępowaniu przed sądem, obejmując również czynności doradztwa oraz techniczne (por. nazwa counsellor-at-law). Stanowi to odstępstwo od przyjętej zasady instruowania barristers przez solicitors $^{64} . Z$ drugiej strony solicitors uzyskali prawo występowania przed sądami wyższymi ${ }^{65}$.

Tradycyjnie przyjmuje się przewagę barristers nad solicitors, czego przejawem były szersze kompetencje dla występowania przed sądami (obejmujące również sądy westminsterskie) oraz często staranniejsze przygotowanie zawodowe (szczególnie w zakresie studiów uniwersyteckich). Jednocześnie swobody związane $z$ funkcjonowaniem UE (swobodny przepływ usług, kapitału, osób) powodują dynamiczny rozwój sektora doradczego, który angażuje głównie solicitors, w związku z czym ta tradycyjna zależność ulega zachwianiu. Zmiany, jakie wprowadzają nowe regulacje prawne, pozwalają przewidywać dalsze zacieranie się różnic, przy czym będzie to $z$ pewnością proces długotrwały.

64 Sformułowanie „to instruct the barrister” świadczy o tym, że barrister powinien opierać się na materiałach dowodowych zgromadzonych i dostarczonych przez solicitor.

65 Na podstawie Access to Justice Act z 1999 r. 


\section{Abstract \\ Historical evolution of an English bar}

In this paper the author examines organisation of the bar in the UK concerning its historical background as well as contemporary structure and operation. Characteristic feature of English system is strong differentiation among legal professions based on ability to act at certain stage of dispute, source of which has been precisely discussed.

The article is divided into three parts. First, the historical one, shows legal professions' birth and its evolution from 11th to 12th century. The second one deals with the matter of self government of the bar as well as the organisation of legal education which is strictly combined with authorities governing the bar. Third and the last part shows the contemporary way to become a solicitor or barrister in the UK. The conclusion of the paper is that the historical differentiation has been strongly blurred and contemporary position of solicitor and barrister became closer than ever.

Keywords: barrister, solicitor, English bar, English judicial system, Law Society, Bar Council 